\title{
IMPROVING ENGLISH VOCABULARY BY USING TOTAL PHYSICAL RESPONSE (TPR) METHOD TO THE FIFTH GRADE STUDENTS OF SDN PASIRKALIKI 1 CIMAHI
}

\author{
Irfan Hidayat1, Aris Munandar2 \\ ${ }^{1}$ IKIP Siliwangi \\ ${ }^{2}$ IKIP Siliwangi \\ ${ }^{1}$ kasetrum7@gmail.com, ${ }^{2}$ ariesmunandar14@gmail.com
}

\begin{abstract}
The objective of this research entitled "IMPROVING ENGLISH VOCABULARY BY USING TOTAL PHYSICAL RESPONSE (TPR) METHOD TO THE FIFTH GRADE STUDENTS OF SDN PASIRKALIKI 1 CIMAHI" was to find out whether or not teaching English Vocabulary using Total Physical Response Method was effective to improve the students' vocabulary ability. The research used quantitative method and one group pretest-posttest design. The population of this research was 31 of the fifth grade elementary school while the sample was entire population. They are consisted of 31 students. The data of this research were collected by giving pretest and posttest to the subject. The collected data were analyzed by using t-test formula. The results of the data analysis showed that: the mean score of pretest was 44.61 , the mean score of posttest was 44.83 , the tobs was 2.442 , the tcritical value at the significance level 0.05 with degree of freedom (df) 30 was 2.042. Based on the data analysis above, the alternative hypothesis was accepted because the tobs was higher than t critical (2.442>2.042). It also meant that improving English vocabulary using Total Physical Response Method was effective to improve the students' vocabulary ability.
\end{abstract}

Keywords: Vocabulary, Total Physical Response Method

\section{INTRODUCTION}

The importance of English as a foreign language causes a phenomenon where English in Indonesia is introduced at earlier stage. One of evidences that appear is when most elementary schools in big cities in Indonesia like Cimahi puts English as one of the subjects at earlier grade. However, some teachers in SDN Pasirkaliki 1 Cimahi find that teaching English to young learners is not an easy thing to do.

Most teachers in the traditional English classroom still use conventional methods in teaching English, for example, memorizing and translating strategy in learning vocabulary as a basic step in learning English.

For the reason above, teachers have to find other methods in improving vocabulary to young learners, which provide a fun enjoyable situation. It is agreed that if students are learning in a fun and enjoyable situation, it will be easier for them to understand and absorb the material. Therefore, the use of alternative methods which provides a fun and enjoyable learning situation is needed, and Total Physical Response (TPR) is one of the methods that can be used in improving vocabulary to young learners. 
According to Ashers (1969), Total Physical Response (TPR) is a method of teaching language using physical movement to react to verbal input in order to reduce student inhibitions and lower their effective filter.

\section{METHOD}

\section{Research Design}

In this research, the researcher used pre-experimental research in one group pretest-posttest as the research design because in this research only the comparator group did not exist and the researcher wanted to know how effective the technique under one group. According to crowl (1996:290) explained that:

Group
Subject $\longrightarrow \mathrm{O}$ 1 $\longrightarrow$ treatment $\longrightarrow \mathrm{x} \longrightarrow \mathrm{O} 2$

(crowl, 1996: 290)

\section{Research Method}

Sugiyono (2009:14) says that: "quantitative research methods can be interpreted as a research method that is based on the philosophy of positivism is used to examine the population or a particular sample, sampling technique is usually done randomly, using a data collection instrument of research, quantitative data analysis/statistics in order to test the hypothesis that predetermined. Thus, this research is going to use quantitative method and adopt one group pretest-posttest design.

\section{Population and Sample}

a. Population

Population is the group of interest to the researcher, the group to whom the researcher would like to generalize the results of the research (fraenkel and wallen, 1990:93). Referred to that definition, the population of this research was the students of the fifth grade of elementary school in cimahi which consists of one class.

b. Sample

The sample of this research was one class of the fifth grade in SDN Pasirkaliki 1 Cimahi that consisted 31 students and it was chosen based on random sampling technique. The research was conducted for about a month.

\section{Research Instrument}

There was a type of instrument used in this research was a practical test. The practical test was conducted to the pretest before the sample get treatment and to the post test after the sample get treatment.

\section{Data Collection Technique and Analysis}

a. Data collection Technique

Data collection is a term used to describe a process of preparing and collecting data, for example, as part of a process improvement or similar project. The purpose of data collection is to obtain information to keep or record, to make decisions about important issues, to pass 
information on to others. Primarily, data are collected to provide information regarding a specific topic.

\section{b. Analysis}

1) Procedures of analyzing the data

In order to analyze the data, there are some steps as follows: a). Collecting the number of population and sample of the research. They are the students of the fifth grade of SDN Pasirkaliki 1 Cimahi; b) Determining the subject of the research; c) Conducting pretest; d) Giving the treatments to subject group, using Total Physical Response method; e) Administering the posttest; f) Collecting and interpretating the pretest and posttest.

2) Technique for analyzing the data

To formulate the result of the test, it needed the compatible formula for getting the result significantly. Whereas the research was a quantitative research by using one group pretestposttest design, the research used the $t_{\text {test }}$ formula.

To find out the result of $t_{\text {test }}$. The researcher needed application which work fast, accurate and credible. There is a computer program which is able to cover those needs, that is SPSS computer program. This program is also used to obtain the Mean, Standard Deviation and normal distribution test.

\section{RESULTS AND DISCUSSION}

\section{Results}

a. analysis of the result of students' pretest score

The pretest was given to the subjects without any information before so that the researcher could get the information of vocabulary mastery and knowledge of the students.

The researcher conducted some procedures to find out mean and standard deviation from the data. Then, the results were found. The descriptive statistics of pretest is described in table 1 .

Table 1

Descriptive Statistics of Pretest

\begin{tabular}{|l|l|l|l|l|l|}
\hline & $\mathrm{N}$ & Minimum & Maximum & Mean & Std. Deviation \\
\hline VAR00001 & 31 & 36.00 & 55.00 & 44.6129 & 5.97594 \\
Valid N (listwise) & 31 & & & & \\
\hline
\end{tabular}

1) Mean of pretest

Mean is average of the students' scores. According to Crowl (1996:135), "The mean is the arithmetic average of a set of scores". It is the simply the sum of the scores divided by number of the students. From the result which obtained by SPSS showed that Mean of pretest was 44.61.

2) Standard deviation of pretest 
Standard deviation is the square root of the average squared difference between each score and the mean score, Crowl (1996:140). The result of the standard deviation on the pretest showed 5.97.

b. Analysis of the result of students' posttest score

The posttest conducted to find out does the use of TPR method improve students' vocabulary significantly. It would be the evidence that there was a significant difference in the students' scores before and after the treatment using TPR method in teaching English vocabulary.

After the posttest scores were inputted, the researcher operated the same way as inputting pretest. Then, the results were found. The descriptive statistics of posttest is described in table 2 .

Table 2

Descriptive Statistics of Posttest

\begin{tabular}{cccccc}
\hline & N & Minimum & Maximum & Mean & Std. Deviation \\
\hline VAR00002 & 31 & 34.00 & 60.00 & 47.8387 & 6.05033 \\
\hline Valid N (listwise) & 31 & & & &
\end{tabular}

1) Mean of posttest

From the result which obtained by SPSS showed that Mean of posttest was 47.83 .

2) Standard deviation of posttest

The result of the standard deviation on the posttest was 6.05 .

c. Finding out the $t_{\text {observed }}$ using $t_{\text {test }}$ formula

1) Testing normal distribution

Before computing $t_{\text {test}}$, researcher needed to test normality because normal distribution is condition for conducting the $t_{\text {test. }}$ Then, the result showed in table 3.

Table 3

Tests of Normality

\begin{tabular}{lcccccc}
\hline & \multicolumn{3}{c}{ Kolmogorov-Smirnov $^{\mathrm{a}}$} & \multicolumn{3}{c}{ Shapiro-Wilk } \\
\hline & Statistic & Df & Sig. & Statistic & Df & Sig. \\
\hline VAR00001 & .118 & 31 & $.200^{*}$ & .935 & 31 & .058 \\
\hline VAR00002 & .103 & 31 & $.200^{*}$ & .987 & 31 & .963
\end{tabular}

From information above, it was known that value of significance (sig) for both variables in Shapiro-Wilk test were more than 0.05. As the condition of data distribution can be assumed 
normal if the value is bigger than standard significance $(0.058>0.05,0.963>0.05)$, it can be concluded that the $t_{\text {test }}$ can be conducted.

2) Computing test by Paired Sample $t_{\text {test }}$

After some steps were passed, finally the researcher obtained the result of $t_{\text {observed. The results }}$ are described in table 4.

Table 4

Paired Sample Test

Paired Samples Test



d. Calculating the number of degree of freedom and critical value of $t_{\text {table }}$ at $5 \%(0.05)$ level of the significance with the degree of freedom

According to $t_{\text {table, }}$ the critical value at 0.05 level of the significance with the degree of freedom 30 (two tailed) was 2.042. With the $d f=31-1=30$, at $\mathrm{p}=0.05$ of two tailed, the critical value of $\mathrm{t}$ is 2.442. As the value of the derived $\mathrm{t}$ ( $\mathrm{t}_{\text {observed}}$ ) which showed from the result of SPSS calculation, is bigger than that of the critical $\mathrm{t}\left(\mathrm{t}_{\mathrm{table}}\right) \rightarrow(2.442>2.042)$, and the significance $(2$ tailed) was $0.021(0.021<0.025)$.

\section{Discussion}

There was significant difference score in pretest before getting the treatment and posttest after getting the treatments in several meetings. The score acquired from the result implied that the posttest was better than the pretest. It is shown by the value of the derived $t\left(t_{0}\right)$ is greater than the critical $\mathrm{t}\left(\mathrm{t}_{\text {table }}\right) \rightarrow(2.442>2.042)$. It indicates that the null hypothesis is rejected and alternative hypothesis is accepted. As a result, there is significant difference between pretest before getting the treatment and posttest after getting the treatments.

\section{CONCLUSION}

In this research, improving vocabulary using Total Physical Response (TPR) method to the fifth grade of SDN Pasirkaliki 1 Cimahi can be seen from the result in previous chapter.

It is proved that the $t_{\text {observed }}$ is bigger than the $t_{\text {table }}(2.442>2.042)$. There is a significant difference between pretest and posttest scores. If $t_{\text {observed }}$ is bigger than $\mathrm{t}_{\text {table }}, \mathrm{H}_{\mathrm{o}}$ (null hypothesis) is rejected, $\mathrm{H}_{\mathrm{a}}$ (alternative hypothesis) is accepted. It means that the result of improving vocabulary using Total Physical Response method intensively is more effective than conventional method. 


\section{ACKNOWLEDGMENTS}

This article is dedicated to our family. Thanks for the support.

\section{REFERENCES}

Ashers, J.J. (1969). The Modern Language Journal. San Jose: San Jose State College Press.

Crowl, T.K. (1996). Fundamentals of educational research. USA: Brown \& Benchmark Publisher.

Fraenkel, J.R. and Wallen, N,E. (1990). How to Design and Evaluate Research in Education. New York: McGraw-Hill.

Sugiyono. (2009). Metoda Penelitian Kuantitatif, Kualitatif dan R\&D. Bandung: Penerbit Alfabeta, Bandung. 